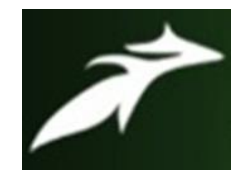

Salina Subba et al, International Journal of Advances in Agricultural Science and Technology,

Vol.8 Issue.8, August-2021, pg. 178-182

ISSN: 2348-1358

Impact Factor: 6.057

NAAS Rating: 3.77

\title{
Sustainability and Profitability of Organic Ginger Growers in South District of Sikkim
}

\author{
Salina Subba ${ }^{1}$ \\ M.Sc. Ag. (Agricultural Extension and Communication) \\ Jahanara ${ }^{2}$ \\ (Head and Associate Professor) \\ Department of Agricultural Extension and Communication, SHUATS (Prayagraj) \\ Neeru Bala ${ }^{3}$ \\ (Associate Professor) \\ Department of Food, Nutrition \& Public Health, SHUATS (Prayagraj) \\ *Author's email: salinasubba648@gmail.com \\ DOI: 10.47856/ijaast.2021.v08i8.019
}

\begin{abstract}
The present study was conducted in South district of Sikkim to study the sustainability and profitability of organic ginger growers. A total number of 120 organic ginger growers were selected proportionately from five villages under Namchi Block because production, productivity and area under organic ginger cultivation were found to be maximum. The data were collected by personal interview method by using pre-tested interview schedule and later appropriate statistical analysis was done to find out the meaningful result. Sustainability indicators with various organic practices have been used to check the sustainability of organic farming practices of organic ginger growers. Whereas, the profitability of the respondents was found to be Rs.11578.57 on an average. Thus, it can be seen that investment of a rupee in organic farming yields 2.57 rupees.
\end{abstract}

KEYWORDS: Sustainability, Profitability, Organic ginger growers, Organic practices, Sikkim

\section{Introduction}

Organic farming has been a way of life and tradition with our farming community over centuries. It is not a new concept to the Indian farming community, especially in tribal areas, hilly regions and arid zones. "Organic" agriculture has however, renewed lately among the farmers and entrepreneurs of high productive areas also for, it has shown potential to increase farm profitability through overall improvements in ecosystem services, bio diversity, soil health and quality, in addition to the production of nutritious food. Organic farming has been a traditional way of farming in Sikkim adopted by farmers since ages. The main horticultural crops are orange \& pears among fruits, ginger, cardamom, turmeric and cherry pepper among spice crops, cole crops, peas \& bean, tomato, potato among vegetable crops. Ginger (Zingiber officinale L.) belongs to the family Zingiberaceae. It is originated from south east Asia Linnaeus derived the genus title Zingiber from its Indian Sanskrit name singabera which means shaped like a horn. Ginger the underground stem, or rhizome, of the plant. Zingiber officinale has been used as spice and medicine in Asian, Indian, and Arabic herbal traditions since ancient times. The prominent varieties that are being cultivated in Sikkim are Bhaise, Gorubathane, Majhaule, Patle, and Jorethang. November to 


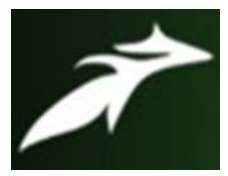

Salina Subba et al, International Journal of Advances in Agricultural Science and Technology,

Vol.8 Issue.8, August-2021, pg. 178-182

ISSN: 2348-1358

Impact Factor: 6.057

NAAS Rating: 3.77

January after 8-9 months of sowing is the optimum time for harvesting ginger. However, this follows the market demand dynamics in Sikkim. Under organic conditions, farmers normally get a yield of 90-100 q/ha depending on ginger cultivation practices.

\section{Research Methodology}

Descriptive research design was adopted for the study as it describes the characteristics or phenomena that are being studied. The present study was conducted in South district of Sikkim. Out of 11 blocks in South district, Namchi block was selected purposively for the present study. From the selected block, five villages namely, Upper Kamrang, Lower Kamrang, Upper Mamley, Lower Mamley and Tinzer were selected purposively where maximum number of farmers grows ginger.

The primary data were collected with the help of interview schedule, which was prepared on the basis of the objectives of the study. The statistical tools like frequency, percentage, mean, standard deviation was used to interpret the data and for drawing the logical conclusion.

\section{Objectives of the Study:}

1. To examine the Sustainability and Profitability of the organic ginger growers.

\section{Results and Discussion}

Table.1. Overall distribution of sustainability of organic ginger practices

\begin{tabular}{|c|c|c|c|c|c|c|c|c|c|c|c|}
\hline \multirow[t]{3}{*}{ S. No. } & \multirow{3}{*}{$\begin{array}{l}\text { Sustainability } \\
\text { indicators }\end{array}$} & \multicolumn{10}{|c|}{ Organic practices } \\
\hline & & \multicolumn{2}{|c|}{$\begin{array}{c}\text { Land } \\
\text { preparation } \\
\text { and seed } \\
\text { treatment }\end{array}$} & \multicolumn{2}{|c|}{$\begin{array}{c}\text { Weed } \\
\text { management }\end{array}$} & \multicolumn{2}{|c|}{$\begin{array}{c}\text { Nutrient } \\
\text { management }\end{array}$} & \multicolumn{2}{|c|}{$\begin{array}{c}\text { Plant } \\
\text { protection } \\
\text { measures }\end{array}$} & \multicolumn{2}{|c|}{ Seed storage } \\
\hline & & $F$ & $\%$ & $f$ & $\%$ & $F$ & $\%$ & $f$ & $\%$ & $F$ & $\%$ \\
\hline $\mathbf{A}$ & Sustainability: ecolog & al dir & nsion & & & & & & & & \\
\hline 1 & Conserve soil quality & 92 & 76.67 & 86 & 71.67 & 89 & 74.17 & 12 & 10.0 & 7 & 5.83 \\
\hline 2 & $\begin{array}{l}\text { Conserve the quality } \\
\text { and availability of } \\
\text { water }\end{array}$ & 86 & 71.67 & 64 & 53.33 & 14 & 11.67 & 7 & 5.83 & 12 & 10.00 \\
\hline 3 & Increase biodiversity & 89 & 74.17 & 32 & 26.67 & 27 & 22.50 & 45 & 37.50 & 31 & 25.83 \\
\hline 4 & $\begin{array}{l}\text { Avoids spread of } \\
\text { hazardous substances }\end{array}$ & 9 & 7.5 & 79 & 65.83 & 16 & 13.33 & 57 & 47.50 & 46 & 38.33 \\
\hline
\end{tabular}




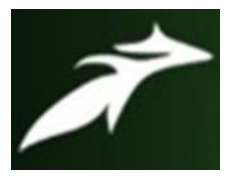

Salina Subba et al, International Journal of Advances in Agricultural Science and Technology,

Vol.8 Issue.8, August-2021, pg. 178-182

ISSN: 2348-1358

Impact Factor: 6.057

NAAS Rating: 3.77

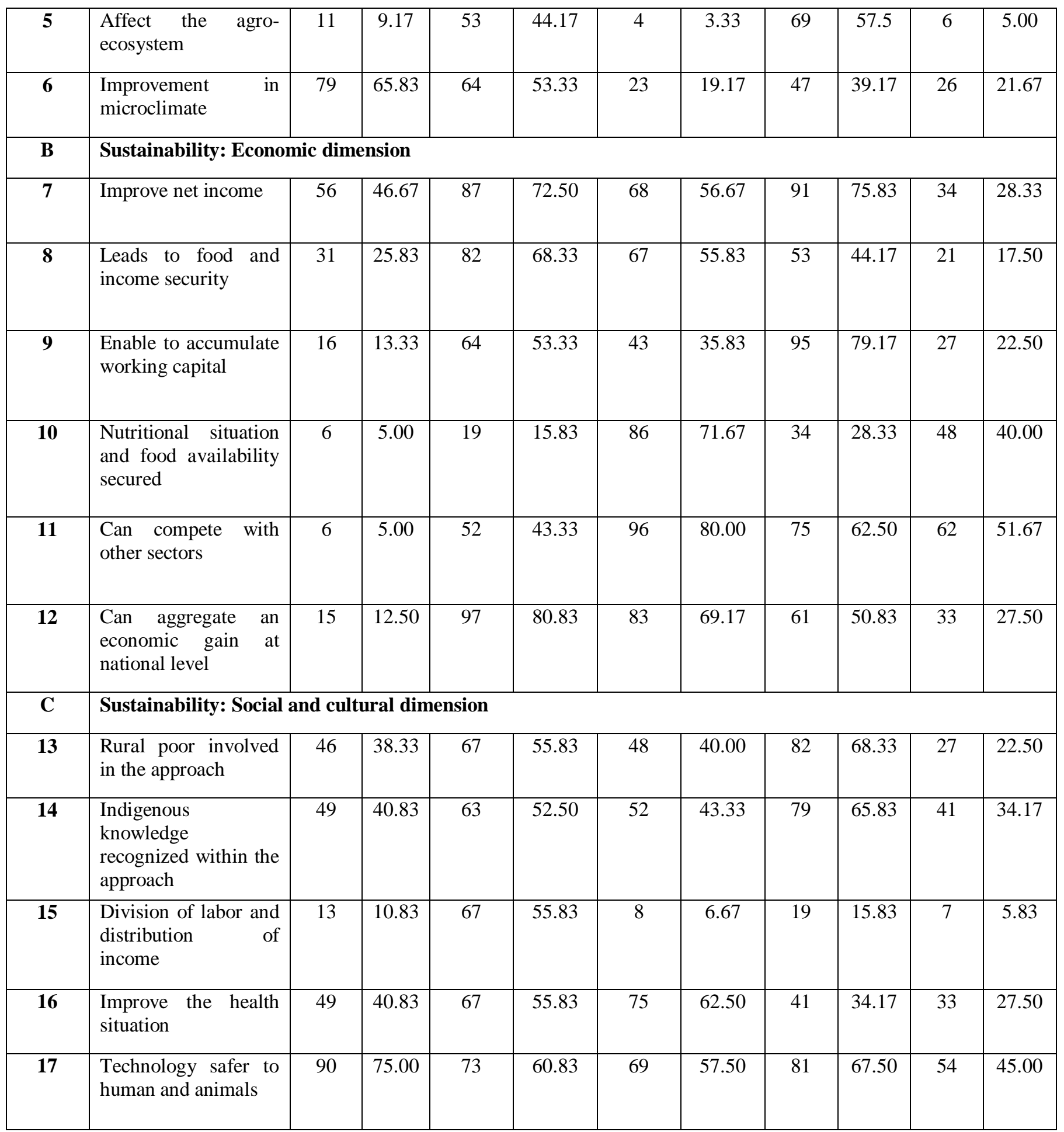




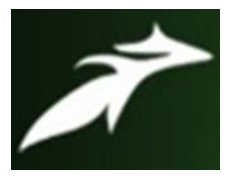

Salina Subba et al, International Journal of Advances in Agricultural Science and Technology,

Vol.8 Issue.8, August-2021, pg. 178-182

ISSN: 2348-1358

Impact Factor: 6.057

NAAS Rating: 3.77

From table.1, it was indicated that with respect to ecological dimension; regarding conserving soil quality, conserving quality and availability of water, increase bio-diversity, 76.67, 71.67, 74.17 per cent of organic ginger growers reported land preparation and seed treatment as most favorable practice. With respect to avoiding spread of hazardous substances, 65.83 per cent of organic ginger growers reported nutrient management as most favorable practice and improvement in micro-climate, 65.83 per cent of organic ginger growers reported land preparation and seed treatment as most favorable practice. With respect to leads to food and income security, 25.83 per cent of organic ginger growers reported land preparation and seed treatment. With respect to competing with other sectors, 5 per cent of organic ginger growers reported land preparation and seed treatment, nutrient management (43.33\%), With respect to social and cultural dimension, 38.33 per cent, 55.83 per cent of organic ginger growers reported land preparation and seed treatment regarding rural poor involved in the approach. With respect to indigenous knowledge recognized within the approach, 40.83 per cent of organic ginger growers reported land preparation and seed treatment, 75 per cent, 60.83 per cent, 57.50 per cent, 67.50 per cent and 45 per cent of organic ginger growers reported land preparation and seed treatment, nutrient management, weed management, plant protection measures and seed storage respectively regarding technology safer to humans and animals.

Table.2. Overall Profitability in organic ginger farming

\begin{tabular}{|c|c|c|}
\hline Sl. No. & Various costs involved in organic farming & Average cost involved (in Rs) \\
\hline $\mathbf{A}$ & \multicolumn{2}{|l|}{ Operational cost } \\
\hline 1 & Labour cost & 4138.16 \\
\hline 2 & Transport cost & 1472.38 \\
\hline \multirow[t]{2}{*}{3} & Sowing cost & 410.72 \\
\hline & Total operation cost & 4503.93 \\
\hline B & \multicolumn{2}{|l|}{ Returns } \\
\hline 1 & Main product & 9810.00 \\
\hline \multirow[t]{2}{*}{2} & Mother rhizome & 6272.50 \\
\hline & Total returns & 16082.50 \\
\hline $\mathbf{C}$ & Profit (Total cost - Returns) & 11578.57 \\
\hline \multicolumn{2}{|r|}{ Benefit - Cost (B:C) ratio } & 2.57 \\
\hline
\end{tabular}

From table.2, it was reported that the total labour cost involved in ginger cultivation was Rs.4138.16 on average basis. The total transport cost involved in ginger was Rs.1472.38 on average basis. The sowing cost involved in ginger cultivation was Rs.410.72 on average basis. Thus, the total operational cost involved in ginger cultivation was Rs. 4503.93 on an average. Meanwhile, the returns on ginger under main product was Rs.9810.00 and the mother rhizome was Rs.6272.50 on average. Hence, the total returns obtained through ginger cultivation under organic farming was Rs.16082.50. Whereas, the profitability 


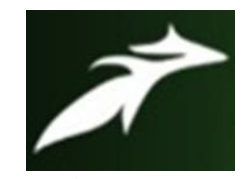

Salina Subba et al, International Journal of Advances in Agricultural Science and Technology,

Vol.8 Issue.8, August-2021, pg. 178-182

ISSN: 2348-1358

Impact Factor: 6.057

NAAS Rating: 3.77

of the organic ginger growers was found to be Rs.11578.57 on an average. Thus, it can be seen that investment of a rupee in organic farming yields 2.57 rupees.

\section{Conclusion}

It was concluded that the majority of the respondents reported that land preparation and seed treatment help in sustainability in terms of ecological dimension. Further, the majority of the respondents reported that the plant protection measures help in sustainability in terms of economic dimension. Simultaneously, majority of the respondents reported that the plant protection measures and land preparation and seed treatment help in sustainability in terms of socio and cultural dimension. It can also be concluded that the profitability of the organic ginger growers was found to be Rs.11578.57 on an average. Thus, it can be seen that investment of a rupee in organic farming yields 2.57 rupees.

\section{References}

[1]. Asokan, R. and Murugan, D 2018. Sustainable Agriculture through Organic Farming in India Multidisciplinary Global Journal of Academic Research5 (5): 27-34.

[2]. Chettri, P. and Guadade, B.A. 2013. Organic production of ginger: A Prominent Sub-Himalayan Spice Popular Khetil (4):207-210.

[3]. Kumar, Santosh; Reddy, G. and Sangwan, P.S. 2017. A review on Organic Farming-Sustainable Agriculture Development International Journal of pure \& Applied Bioscience 5(4): 1277-1282.

[4]. Vijayan, A.K; Guadade, B.A.; Gautam, Ashutosh ; Deka, T.N.; Bora, S.S.; Dhanapal, K. and Remashree, A.B. 2020. Cultivation of Ginger in Sikkim under an Organic System Ginger Cultivation and its Antimicrobial and Pharmacological Potentials, Haiping Wang. https://www.intechopen.com/chapters/68348

[5]. Yadav, S. K.; Babu, Subash; Yadav, G.S.; Singh, Kalyan; Yadav, G.S. and Pal, Suresh 2013. A review of organic farming for sustainable agriculture in Northern India Hindawi Publishing Corporation International Journal of Agronomy 1-8. 